原著

レジン充填窩洞のシアノアクリレート処理について

福 士 良 雄

東京医科歯科大学第 1 菌科保存学教室 (主任指導 : 総山孝雄教授)

（1978年 3 月 24 日受付）

\section{Cyanoacrylate Treatment of Cavity Walls for Composite Resin Restoration}

\section{Yoshio Fukushi}

Dept. of Operative Dentistry, School of Dentistry, Tokyo Medical and Dental University

(Director: Prof. Takao Fusayama)

要旨：複合レジン充填䆚洞のシアノアクリレート処理の効果を検討するために，処理をした場合としなか つた場合につき，複合レジンの柬質面に対する接着力を測定し，また抜去歯牙および口内の歯牙に施した複 合充填の漏洩度を墨汁法により検討した。また, シアノアクリレート処理の歯髄刺激についても臨床的に検 討し，次のような知見を得た。

1. 乾燥した歯質には, シアノアクリレートはかなり強力な接着力を示したものの, 水中に保管した場合 にはほとんど零に近くなった。

2. 䆚洞をシアノアクリレート処理して複合レジンを填塞した場合には, 無処理の場合に比べて漏洩が著 しく防止され，温度変化を与えた場合にも，やはり漏洩防止効果には変わりなかった。

3. シアノアクリレート処理は菌髄刺激をわずかに増加したが， 4 週後には全く消失した。

4. エチルシアノアクリレートはメチルシアノアクリレートよりも, 接着力が勝り, 漏洩が少なく, 歯髄 刺激も少なかった。

\section{緒論}

ら蝕の保存修復にあたって, 歯質に化学的に強 固に接着する材料の開発が，長年歯科界で望まれ てきた。しかし未だ完全な材料は出現せず，この ため窩洞形成は従来の原則に従い健全歯質の一部 を削除して，機械的な保持形態を求めているのが 現状である。

しかし, 近年この種の研究が広く行われるよう になり, Buonocore は歯質を酸により処理し，レ ジンの接着力を高めることを試みた1,2)。
これは歯質表面に極性を生じ, 化学的な結合力 を，強化するといら考光もあるが3,4)，やはりそ の大部分は, 酸蝕された凹部にレジンが浸入して できるタグによる，機㭜的な嵌合抗力によるもの である゙)。しか子酸の使用については, 歯髄刺激 や5,6)，必要以上の歯質の破壊を伴う危険につい ての報告が多く7)，決して理想的な方法であると はいえない。

そこでBowen は，酸による前处理なしに歯質 と充填物との接着力を増加させるために，歯質と 子複合レジンとも化学的纪結合するカップリング 
剂を用いることを提唱した ${ }^{8 \sim 12)}$ 。この考えに基づ いて作られた材料の実験を行った大串らは，その 成績が臨床上決して満足しうる值ではなかったと 報告している13)。

一方 Smith は, ポリカルボキシレートセメン トを考案した ${ }^{14)}$ 。この材料は, 酸化亜鉛の粉末と ポリアクリル酸の液を練和するもので, 従来のリ ン酸垔鉛セメントに比較して，歯髄刺激が少な く15)，キレーションにより歯質に対する化学的接 着性を有する点副など，きわめてすぐれた性質を 示すニニークな材料であるが，色調は白く不透明 であり，外観にふれるところの単独修復物として は用いられない17)。

またWilson らは，カルボキシレートセメント と同様キレーションにより歯質と化学的に反応し 接着するグラスアイオノマーセメントを考案し た18)。このセメントは, 粉末にカルシウムアルミ ノシリケートグラスを用い, 液にはポリアクリル 酸を用いるもので，カルボキシレートセメントと 比較して, 透明度はあるものの, 単独修復物として は臨床上しばしば起こる表面の白濁 ${ }^{19)}$ や崩壊率 ${ }^{20}$, 21)，合着力としては被膜厚の点で問題が多い20, 21)。

近年合成化学の進歩とともに，一般工業界では 各種の接着削が生産され広く用いられており, そ の中から歯科保存修復に適したものを, 接着力強 化のために用いようとする試みがなされるよらに なった。Beech はシアノアクリレートを接着力強 化のために用い，かなりの接着力を示し有望であ ると報告した ${ }^{22)}$ 。

レジン充填に関するもら一つの重要な問題点 は，歯質との間の吵間発生による漏洩である。現 在臨床で用いられている修復物には化学的な接着 力がないために, 重合収縮23), 口腔内の温度変 化 ${ }^{23)}$, 填塞時の操作法 ${ }^{24)}$, などにより, 隙間を生 じることが多い。このような隙間の存在は, 細 菌, 酸または酵素を含む口腔液が浸入し, 歯髄刺 激を起こしたり，二次ら蝕の原因となるといわれ ている25)。またこのような隙間への色素の浸入 は, 充填物全体に変色状の様相を示し, 審美的に
問題となることがしばしば認められる

そこで本研究は，歯質を酸処理することなく， 化学的に歯質に接着し修復物の保持を強化すると 同時に漏洩を防ぐ目的でシアノアクリレートを用 い，その効果について基礎的ならびに臨床的実験 を行い，興味ある知見を得たので，ここに報告す る。

\section{材料および方法}

\section{I．接着力試験}

\section{1. 被接着面の作製}

人の抜去歯を用い，エナメル質面としては，ら 蝕のない中切歯88本の唇面を，象牙質面としては 大曰歯88本の咬合面を，注水下で丸本工業社製の 湿式研磨紙\#240～\#600末で研磨し，超音波洗浄後 アルコールで清掃し, 手用気銃で乾燥して被接着 面とした。

\section{2. 接着試片の作製}

清掃乾燥した研磨歯面に，シアノアクリレート を, 市販の容器から 1 滴滴下し, 膜状に広がった その上に, 内径 $5 \mathrm{~mm}$, 高さ $3 \mathrm{~mm}$ の切り口の平 坦なテフロンチューブを置き，位置がずれないよ らにひし型のテフロン板と輪ゴムで固定した後 (図 1), 練和した複合レジンを填入し，その中に 引っ張り試験に利用するために，釣り用樽型サル カンをさし込んで, 温度 $23 \pm 2^{\circ} \mathrm{C}$ 相対湿度 $50 \pm 10$ \%の室内に15分放置して硬化させた。

シアノアクリレートとしては, メチルシアノア クリレート（セメダイン 3000, セメダイン株式会 社, 東京) とエチルシアノアクリレート(セメダイ

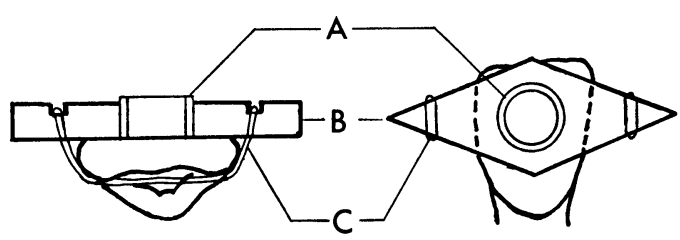

図 1 接着試片の側視断面図（左）と正面図（右）
A テフロンチューブ
B テフロン板
C 輪ゴム 


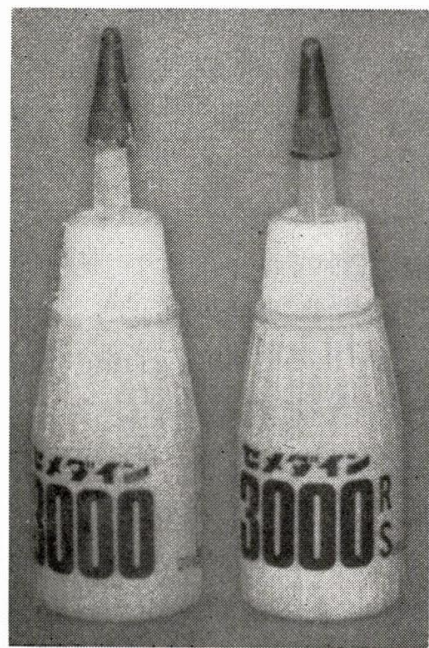

図 2 実験に使用したメチルシアノア クリレート（左）とエチルシア ノアクリレート（右）

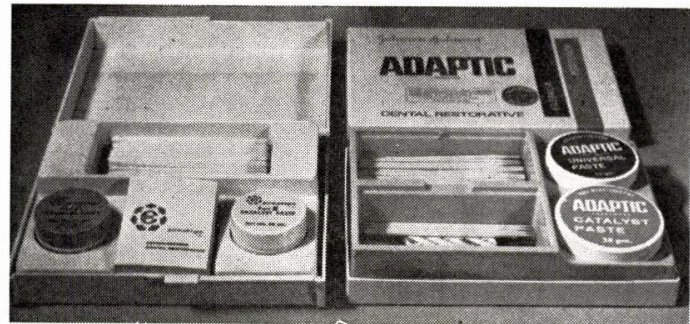

図 3 実験に使用した複合レジン Prestige（左）と Adaptic (右)

ン $3000 \mathrm{Rs}$ ，セメダイン株式会社，東京）の 2 種を (図 2), 複合レジンとしては Adaptic (Johnson \& Johnson, East Windson, N. J., U. S. A., B. N. Al3JF) と Prestige (Lee pharmaceutical, South Elmonte, Calif., U.S.A., B. N. 061876HP-1) の 2 種を用いた（図 3 ）。15分後, 鋭利な外科用入ス でテフロンチューブを切断し，歯面に膜状に広が っているシアノアクリレートの溢出部とともに除 去した。接着試片は 2 つの゙ループに分け，それ ぞれ温度 $23 \pm 2{ }^{\circ} \mathrm{C}$, 相対湿度 $50 \pm 10 \%$ の室内, も しくは温度 $37^{\circ} \mathrm{C} の$ 蒸留水中に 14 日間保管した。

3. 接着力の測定

オートグラフ S-500（島津製作所, 京都) に,
総山の考案した接着力測定用装置（図 4) をセッ トして測定した。本装置は，図の拈もりにより初 期荷重がバランスするように設計されており，そ のため荷重 0 の状態から接着力が測定できるとい ら特徵を持つものである。測定はクロスヘッドス ピード $0.8 \mathrm{~mm} / \mathrm{min}$ 。フフスケール $20 \mathrm{~kg}$ で各 群10例ずつ行い, 歯質とレジンが剥離した時の荷 重を, 単位面積あたりの荷重に換算して接着力と した。

\section{II. 漏洩試験}

1. 拔去歯による実験

a、試片調整

ら蝕のない人の抜去上顎中切歯40本を用い， マ ネキンに固定したプラスチック製顎模型の上顎中 切歯部に一度に 2 本ずつ植立固定し, 通法に従っ てタービンに付けた 770 のカーバイドバーで唇面

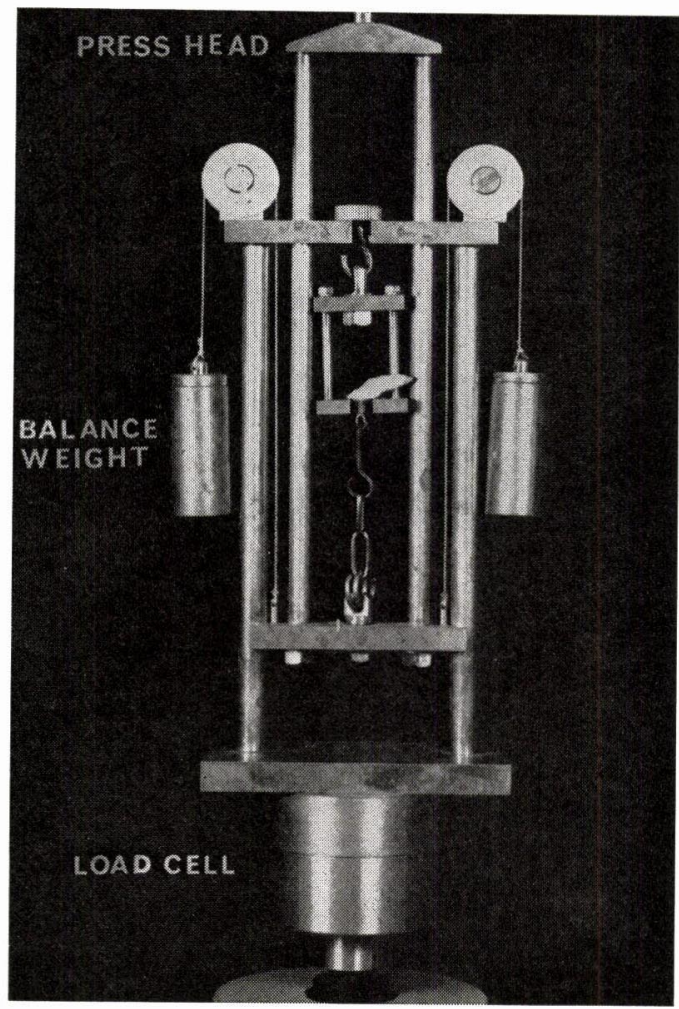

図 4 無圧接着力の引張り試験装置

バランスウエイトによって引張り部の重量が消 去してあるので, 接着力は零のオーダーから測定 しうる。 
に 5 級窩洞を形成し，マイクロモーターに付けた \#1/2のラウンドバーにより円形穿下を付与した。 20本はそのまま Adaptic (B. N. A13JF) を填塞 し, 残りの 20 本は窩洞に数滴シアノアクリレート を滴下した後, 手用気銃で過剩部を吹き飛ばし, Adaptic (B. N. A13JF) を填塞し, 両者とも $37^{\circ} \mathrm{C}$ の蒸留水中に保管した。48時間後にとり出し, 仕 上げ研磨後, シアノアクリレート処理をほどこし た試片 10 本と無処理の試片 10 本を一群とし，一群 は $37^{\circ} \mathrm{C}$ 墨汁（カイメン墨汁 12 号）に 24 時間浸漬 し，もら一群は墨汁を用いたサーマルサイクル装 置により各々漏洩試験を行った。サーマルサイク ルは教室で新たに考案した装置(図 5 ) により，4 ${ }^{\circ} \mathrm{C}, 37^{\circ} \mathrm{C}, 60^{\circ} \mathrm{C}$ の三段階の温度の墨汁を用い，浸 漬時間各 1 分, 浸漬と浸漬のインターバルは30秒 で，240サイクル行った。

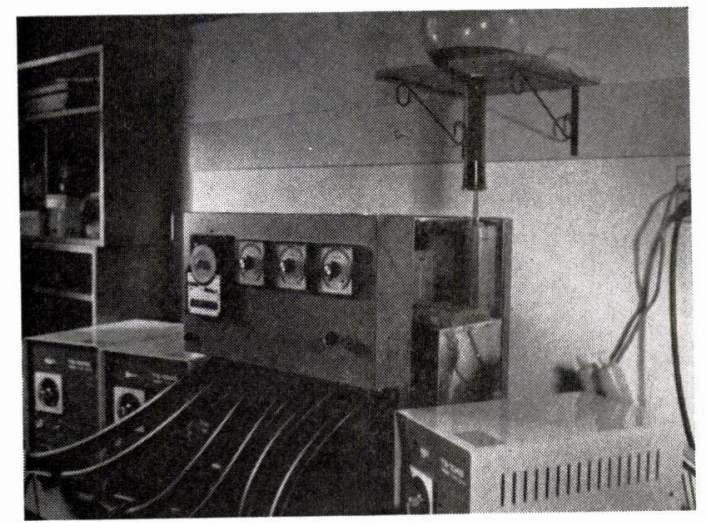

図 53 温 $\left(4,37,60^{\circ} \mathrm{C}\right)$ 式サーマルサイクル装置

\section{b 。漏洩度の測定}

浸漬またはサーマルサイクル終了後, 流水下で 30 秒洗浄し, 試片を観察写真撮影後, 硬組織薄切 機を用い，充填物のほぼ中心を通るよらに歯軸に 沿って切断し, その断面を顕微鏡下で観察し, 歯 肉側および歯頂側のエナメル壁, 象牙質側壁, 窩 底穿下部和よび窩底中央部に括ける墨汁浸入の有 無ならびに隅角部気泡の有無を検索した。そして 墨汁浸入の有無により+, 一の 2 段階とし, それ ぞれ 1,0 の指数に置きか党, 各群各観察部位の 指数の合計を被検例数で割ることによって平均指
数を求め各群の成績を比較検討した。

c . 接着部断面の電子顕微鏡観察

抜去歯による漏洩試験と同じ方法で作製した， 無処理または土チルシアノアクリレート処理し て, 複合レジンを充填した試片各一本を $37^{\circ} \mathrm{C}$ の蒸 留水中に14日間保管し, 注水下で硬組織簿切機で 縦断した。走査型電子顕微鏡観察のためには, 表 面張力が作用しないために, 通常の乾燥法のよう な試料の収縮やひび割れが起こりにくいといわれ ている臨界点乾燥法を用いて ${ }^{27)}$, 試料の乾燥を行 った。すなわち, 縦断した切片を酢酸イソアミル に浸漬し, 次に耐圧容器内で液体二酸化炭素で置 換して酢酸イソアミルを除き，そして液体二酸化 炭素を気化させて乾燥させた。そして，真空中で 炭素抽よび金を蒸着し, 走査型電子顕微鏡により 観察した。

\section{2. 臨床試験}

a 、試験症例の選択および準備

本学附属病院保存科外来を訪れた 16 人の患者を 被験者とし， 3 級， 4 級， 5 級および楔状欠損の 症例を用いて臨床試験を行った。まず通法により 窝洞形成し，清掃乾燥を行った。そのうち19例に は, 裏層せずに直接 Adaptic を充填し, 残りの 38例には, メチルシアノアクリレートとェチルシ アノアクリレートとを $1 \sim 2$ 滴滴下後, フッ素樹 脂のチップの付いた複合レジン充媜器により窩洞 全体に塗布し，気銃によって過剩部分を除いて， Adaptic を充填した。

\section{b 。漏洩度の測定}

填塞 1 週間後, 通法に従ってタングステンカー バイドの仕上げ用バー, スチールストリップス, ラ バーカップにつけたポリペースト A， B 执よびプ ラスチックストリップスなどを, 症例に応じて用 いながら研磨を行った。その後墨汁を被検歯全面 に塗布し， 5 分間そのままにした後水銃により洗 い流し，さらに水を含ませた小綿球を取り換えな がら3 回霜面を拭った。そして辺縁への墨汁の浸 入による着色の様子を, 明瞭な太い黒線のあるも のを+, 若干着色があっても明膫でないものや, 全く着色のないものを一の基準で判定して記録し 
た。なお参考のために写真撮影も行った。そして 研磨時に墨汁の浸入のあった症例もそのまま帰宅 させ, ブラッシングの影響による変化を観察し た。各症例について同様の漏洩試験を, それぞれ 充填後, 1, 2, 4 週後に行った。

\section{成 績}

\section{1. 接着試験成績}

各群の歯質面汶対する接着力を比較して（表 1 )，下記のような知見が得られた。

保管条件については, 空気中のものは温水中の ものに比べ，いずれの条件下でも，有意差をもっ て接着力が大きかった。

2 種のシアノアクリレートの間では, 温水中に 保管した場合には，いずれのレジンを填めた場合 でも，エナメル質象牙質のいずれに対しても，エ チルシアノアクリレート処理がメチルシアノアク リレート処理よりも，大きな接着力を示した。空 気中に保管した場合には，エチルシアノアクリレ ート処理とメチルシアノアクリレート処理との間 に統計学的に有意な接着力差を示さず, 平均值に よる比較に扮いても傾向は区々であった。
表 1 シアノアクリレート処理歯質面への接着力

$\left(\mathrm{kg} / \mathrm{cm}^{2}\right)$

\begin{tabular}{|c|c|c|c|c|}
\hline \multirow{2}{*}{ 接着 面 } & \multirow{2}{*}{ 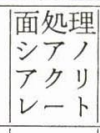 } & \multirow{2}{*}{ 保 管 } & \multicolumn{2}{|l|}{ 材 } \\
\hline & & & Adaptic & Prestige \\
\hline \multirow[t]{4}{*}{ エナメル質 } & \multirow[t]{2}{*}{ メチル } & 空気中 & $7.03(2.5)$ & 7.39 ( 3.8$)$ \\
\hline & & 温水中 & $1.89(0.8)$ & $0.82(0.6)$ \\
\hline & \multirow[t]{2}{*}{ エチル } & 空気中 & 14. $93(5.7)$ & $5.85(2.4)$ \\
\hline & & 温水中 & 3. $01(1.2)$ & 1. $73(1.1)$ \\
\hline \multirow[t]{4}{*}{ 象牙質 } & \multirow[t]{2}{*}{ メチル } & 空気中 & $48.96(9.7)$ & 45.09 (12.7) \\
\hline & & 温水中 & $2.06(0.8)$ & $1.63(0.6)$ \\
\hline & \multirow[t]{2}{*}{ エチル } & 空気中 & $52.78(16.0)$ & $37.09(6.5)$ \\
\hline & & 温水中 & $4.23(1.7)$ & $4.84(2.6)$ \\
\hline
\end{tabular}

エナメル質と象牙質を比較すると，温水打よび 空気中のいずれに保管した場合にも象牙質面への 接着力がェナメル質面への接着力より大きく，そ の差は, 温水中保管群のほらが大きかった。

複合レジン材料間で比較すると, 温水中に保管 した場合には，一般に Adaptic がPrestige より
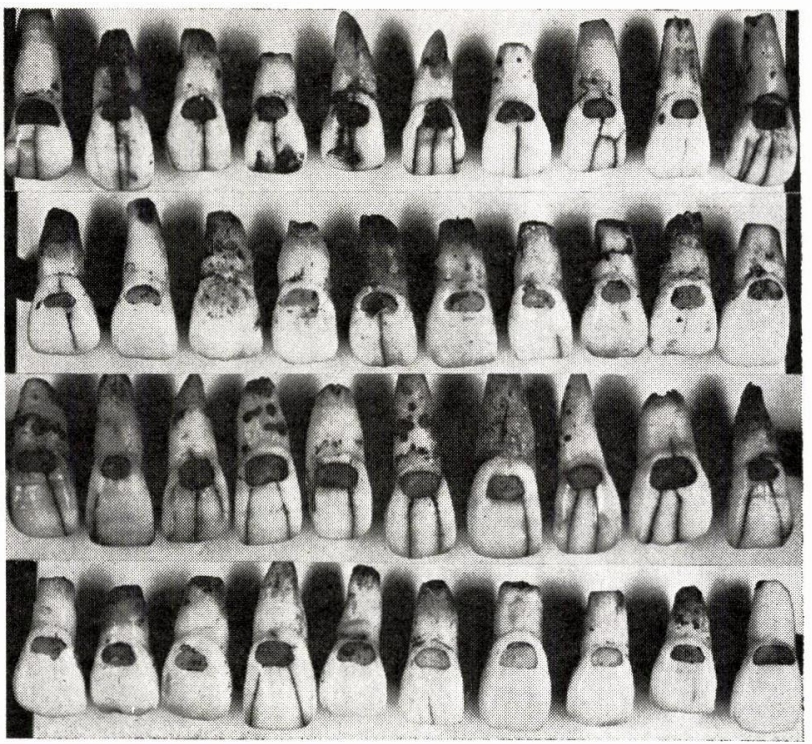

図 6 研磨後の 24 時間墨汁処理による漏洩度の差

U N T : 無処理 $37^{\circ} \mathrm{C}: 37^{\circ} \mathrm{C}$ 墨汁に浸漬 $\mathrm{CAT}$ ：シアノアクリレート処理 $\mathrm{TH} \mathrm{C}$ ：墨汁中で温度変化
大きな接着力を示した。ただし， 象牙質をエチルシアノアクリレー トで処理した場合には, Prestige が Adaptic より大きな接着力を 示したが，統計的有意差はなかっ

C A T た。空気中に保管した場合も，一 T H C 般に Adaptic が Prestige より大 きな接着力を示した。ただし，エ ナメル質面をメチルシアノアクリ

U N T $37^{\circ} \mathrm{C}$

C A T

T H C レートで処理した場合には, PrestigeはAdapticより大きな接着力 を示したが，統計的有意差はなか った。

\section{2. 拔去歯による漏洩試験成績}

a . 表面観察所見

墨汁により漏洩試験を行って抜 去歯を表面から観察し，次のよう な所見が得られた（図6，7）。 


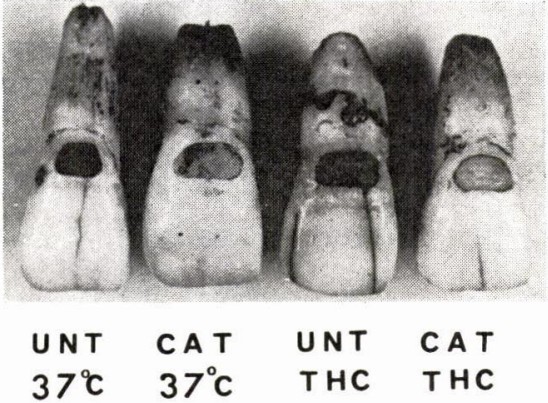

図7図6 の代表例

U N T : 無処理

$37^{\circ} \mathrm{C}: 37^{\circ} \mathrm{C}$ の墨汁に浸漬

C A T ：シアノアクリレート処理

$\mathrm{TH} \mathrm{C}$ : 墨汁中で温度変化

温度変化を与党なかった群の無処理のグループ では, 複合レジン充媜物と窩縁との間に，注㵝 洞全周にわたり肉眼ではっきり認められる程強い 黒線が発生したのみならず，充填物が全体的に強 く黒ずんでいたが，エチルシアノアクリレート処 理したグループでは，黒線は一部（主として歯肉 側）にわずかに発生しているのみで，若干の表面 着色例はあったが，全体が黒ずんでいるものはな
かった。

温度变化を与党た場合にも，無処理のグループ では，やはり複合レジン充填物と窩縁との間に， 窩洞全周にわたる強い黑線が発生し, 充塤物全体 が黒ずんでいたが，エチルシアノアクリレート処 理したグループでは，黒線は一部にわずかに発生 しているのみで，若干の表面着色例はあったが， 充填物全体が黒ずんでいるものはなかった。この ような変化の程度は, 温度変化を与えなかった場 合と与えた場合との間に，汪とんど差が見られな かった。

\section{b. 断面観察所見}

抜去歯の縦断面による観察により下記の所見が 得られた（図 8,9 )。

温度変化を与えなかった場合には，無処理のグ ループでは窩底穿下部あるいは窩底中央部まで黒 線が発生し，充填物全体が黒ずんでいたが，エチ ルシア,アクリレート処理したグループでは, 一 部にわずかに歯肉側に発生しているのみで, 充填 物全体が黒ずんでいるものはなかった。

温度変化を与えた場合でも, 無処理のグループ は窩底穿下部あるいは窩底中央部まで黒線が発生

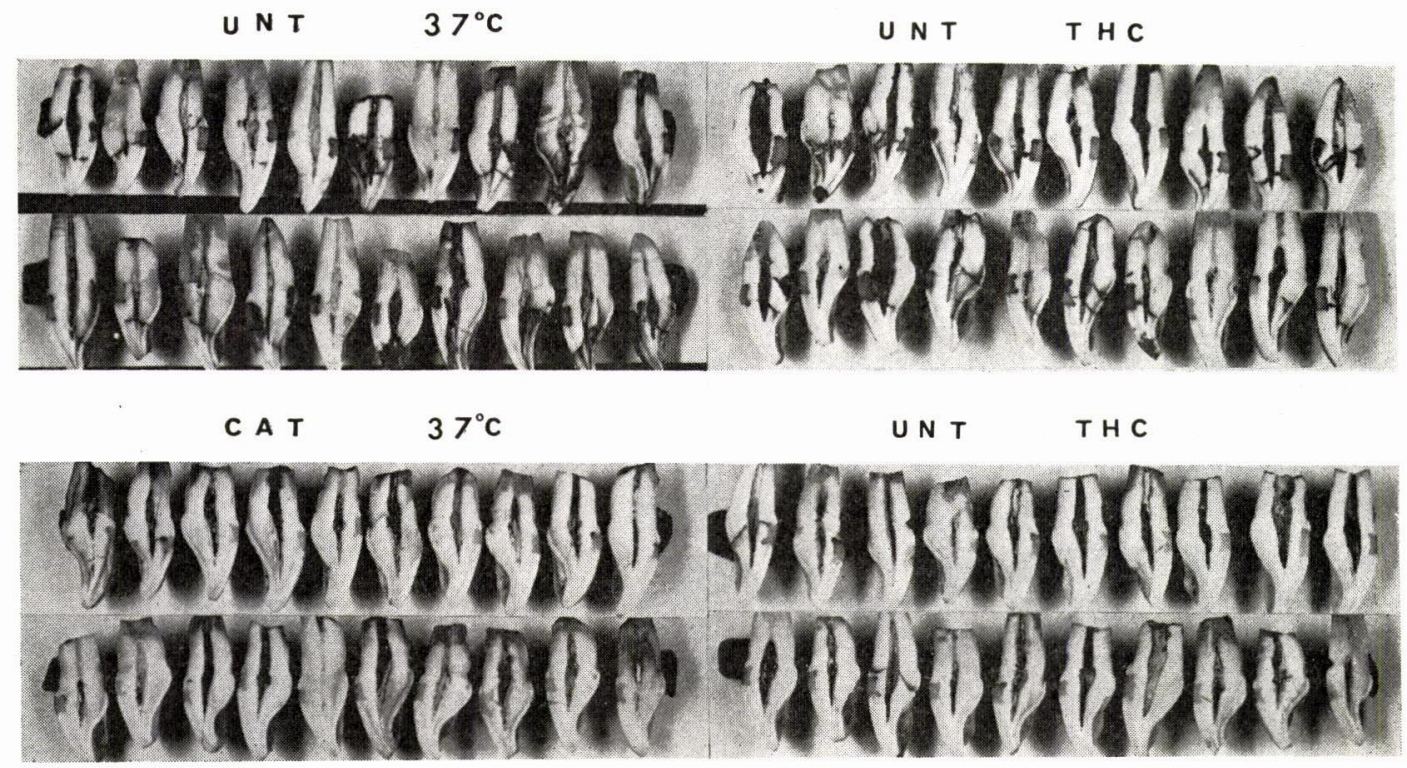

図8四6の歯牙の縱断面 $\mathrm{CAT}$ : 無处理, $37^{\circ} \mathrm{C}: 37^{\circ} \mathrm{C}$ 墨汁に浸漬, CAT : シアノアクリレート处理, $\mathrm{THC}$ : 墨汁中で温度変化 


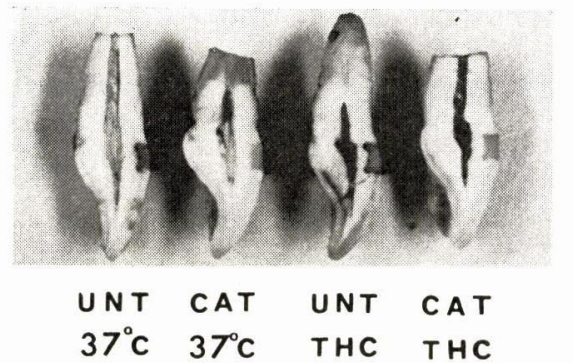

図 9 図 8 の代表例

UNT : 無処理

$37^{\circ} \mathrm{C}: 37^{\circ} \mathrm{C}$ の墨汁に浸漬 CAT : シアノア クリレート処理 THC : 墨汁中で温度变化
し，充填物全体が黒ずんでいたが，エチルシア， アクリレート処理したグループでは数例歯肉側象 牙質内に黒線が認められたものの, やはり一部に わずかに歯肉側に発生している例が大部分を占め ており, 充填物全体が黒ずんでいるものはなく, 温度変化の有無による差は無処理の場合にも, シ アノアクリレート処理の場合にも確認できなかっ た。

その断面を顕微鏡下で観察し, 墨汁浸入拈よび 隅角部気泡の有無により+と一の二段階とし, そ れぞれ 1 と00指数を置きかえ，その漏洩指数に

表 2 無処理窩洞に複合レジンを充填した抜去菊の断面で観察された墨汁漏洩度扔よび偶角部気泡

( $37^{\circ} \mathrm{C} 24$ 時間後)

\begin{tabular}{|c|c|c|c|c|c|c|c|c|c|c|c|c|c|c|c|c|c|c|c|c|c|c|}
\hline & No. & 1 & 2 & 3 & 4 & 5 & 6 & 7 & 8 & 9 & 10 & 11 & 12 & 13 & 14 & 15 & 16 & 17 & 18 & 19 & 20 & 平均 \\
\hline エナメル壁 & $\begin{array}{l}\text { 歯頂側 } \\
\text { 眯側 }\end{array}$ & $\overline{+}$ & $\begin{array}{l}+ \\
+\end{array}$ & $\begin{array}{l}+ \\
+\end{array}$ & $\begin{array}{l}+ \\
+\end{array}$ & $\overline{+}$ & \pm & $\begin{array}{l}+ \\
+\end{array}$ & $\begin{array}{l}+ \\
+\end{array}$ & $\begin{array}{l}+ \\
+\end{array}$ & + & + & $\begin{array}{l}+ \\
+\end{array}$ & $\begin{array}{l}+ \\
+\end{array}$ & $\begin{array}{l}+ \\
+\end{array}$ & $\begin{array}{l}+ \\
+\end{array}$ & $\overline{+}$ & $\begin{array}{l}+ \\
+\end{array}$ & $\begin{array}{l}+ \\
+\end{array}$ & $\begin{array}{l}+ \\
+\end{array}$ & $\begin{array}{l}+ \\
+\end{array}$ & $\begin{array}{l}0.85 \\
0.95\end{array}$ \\
\hline 象牙質側壁 & $\begin{array}{l}\text { 歯頂側 } \\
\text { 类側 }\end{array}$ & + & $\stackrel{+}{+}$ & + & + & $\begin{array}{l}+ \\
+\end{array}$ & \pm & + & $\begin{array}{l}+ \\
+\end{array}$ & $\begin{array}{l}+ \\
+\end{array}$ & $\begin{array}{l}+ \\
+\end{array}$ & $\begin{array}{l}+ \\
+\end{array}$ & \pm & $\begin{array}{l}+ \\
+\end{array}$ & $\begin{array}{l}+ \\
+\end{array}$ & $\begin{array}{l}+ \\
+\end{array}$ & $\overline{+}$ & $\begin{array}{l}+ \\
+\end{array}$ & $\begin{array}{l}+ \\
+\end{array}$ & $\begin{array}{l}+ \\
+\end{array}$ & + & $\begin{array}{l}0.95 \\
0.9\end{array}$ \\
\hline 䆚底穿下部 & $\begin{array}{l}\text { 歯頂側 } \\
\text { 迷肉側 }\end{array}$ & $\begin{array}{l}+ \\
+\end{array}$ & $\stackrel{+}{+}$ & + & $\begin{array}{l}+ \\
+\end{array}$ & $\begin{array}{l}+ \\
+\end{array}$ & \pm & + & + & + & $\bar{t}$ & $\begin{array}{l}+ \\
+\end{array}$ & \pm & $\begin{array}{l}+ \\
+\end{array}$ & $\begin{array}{l}+ \\
+\end{array}$ & $\begin{array}{l}+ \\
+\end{array}$ & $\begin{array}{l}+ \\
+\end{array}$ & $\begin{array}{l}+ \\
+\end{array}$ & $\begin{array}{l}+ \\
+\end{array}$ & $\begin{array}{l}+ \\
+\end{array}$ & + & $\begin{array}{l}0.95 \\
0.9\end{array}$ \\
\hline 窩底 & 中央部 & + & + & + & + & + & + & - & + & + & - & + & - & + & + & + & + & + & - & + & + & 0.8 \\
\hline 偶角部気泡 & $\begin{array}{l}\text { 歯頂側 } \\
\text { 类側 }\end{array}$ & $\overline{+}$ & $\overline{+}$ & \pm & $=$ & $\overline{+}$ & $\overline{+}$ & $=$ & $\overline{+}$ & - & $\overline{-}$ & $=$ & $=$ & - & $=$ & $\overline{+}$ & $\overline{-}$ & $=$ & $\overline{-}$ & $\begin{array}{l}- \\
-\end{array}$ & - & $\begin{array}{l}0.05 \\
0.3\end{array}$ \\
\hline \multirow{4}{*}{$\begin{array}{l}\text { 漏 洩 度 } \\
\text { (十数集計) }\end{array}$} & 歯頂側 & 2 & 3 & 4 & 3 & 2 & 3 & 3 & 3 & 3 & 2 & 3 & 3 & 3 & 3 & 3 & 1 & 3 & 3 & 3 & 3 & 2. 8 \\
\hline & 歯肉側 & 4 & 4 & 3 & 3 & 4 & 1 & 3 & 4 & 3 & 3 & 3 & 1 & 3 & 3 & 4 & 3 & 3 & 3 & 3 & 3 & 3. 05 \\
\hline & 全 体 & 7 & 8 & 8 & 7 & 7 & 5 & 6 & 8 & 7 & 5 & 7 & 4 & 7 & 7 & 8 & 5 & 7 & 6 & 7 & 7 & 6. 65 \\
\hline & \multicolumn{22}{|c|}{ 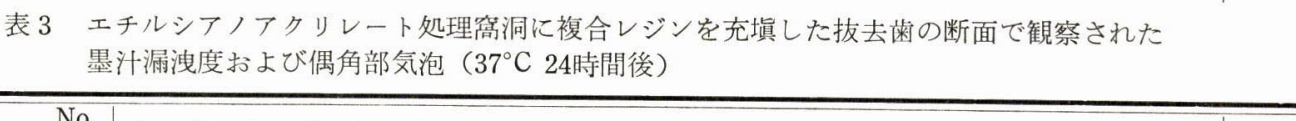 } \\
\hline & No. & 1 & 2 & 3 & 4 & 5 & 6 & 7 & 8 & 9 & 10 & 11 & 12 & 13 & 14 & 15 & 16 & 17 & 18 & 19 & 20 & 平均 \\
\hline エナメル壁 & $\begin{array}{l}\text { 歯頂側 } \\
\text { 歯肉側 }\end{array}$ & - & $\overline{-}$ & $\overline{+}$ & $=$ & - & - & - & - & - & $\bar{t}$ & $\overline{-}$ & $\overline{-}$ & $=$ & $=$ & - & $\overline{-}$ & - & - & $\overline{-}$ & $\begin{array}{l}- \\
-\end{array}$ & $\begin{array}{l}0 \\
0.15\end{array}$ \\
\hline 象牙質側壁 & $\begin{array}{l}\text { 歯頂側 } \\
\text { 齿側 }\end{array}$ & - & $=$ & $\begin{array}{l}- \\
-\end{array}$ & $=$ & I & - & $\begin{array}{l}- \\
-\end{array}$ & $=$ & $=$ & $\overline{-}$ & $\overline{-}$ & $\overline{-}$ & $\overline{-}$ & $\begin{array}{l}- \\
-\end{array}$ & - & - & - & $\overline{-}$ & - & $\overline{-}$ & $\begin{array}{l}0 \\
0\end{array}$ \\
\hline 窩底穿下部 & $\begin{array}{l}\text { 歯頂側 } \\
\text { 畨肉側 }\end{array}$ & $\overline{-}$ & $=$ & - & $=$ & $=$ & - & $=$ & $=$ & $=$ & - & - & $\overline{-}$ & - & $\overline{-}$ & - & $=$ & $=$ & $=$ & - & $=$ & $\begin{array}{l}0 \\
0\end{array}$ \\
\hline 窩底 & 中央部 & - & - & - & - & - & - & - & - & - & - & - & - & - & - & - & - & - & - & - & - & 0 \\
\hline 偶角部気泡 & $\begin{array}{l}\text { 歯頂側 } \\
\text { 歯側 }\end{array}$ & $\overline{-}$ & $\overline{-}$ & $\overline{-}$ & $\overline{-}$ & $\begin{array}{l}- \\
-\end{array}$ & - & - & $\begin{array}{l}- \\
-\end{array}$ & $\overline{+}$ & $\overline{-}$ & $\overline{+}$ & - & 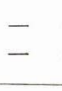 & $\begin{array}{l}- \\
-\end{array}$ & - & $\begin{array}{l}- \\
-\end{array}$ & $\begin{array}{l}- \\
-\end{array}$ & $=$ & - & $\overline{-}$ & $\begin{array}{l}0 \\
0.1\end{array}$ \\
\hline \multirow{3}{*}{$\begin{array}{c}\text { 漏 洩 度 } \\
\text { (+数集計) }\end{array}$} & 歯頂側 & 0 & 0 & 0 & 0 & 0 & 0 & 0 & 0 & 0 & 0 & 0 & 0 & 0 & 0 & 0 & 0 & 0 & 0 & 0 & 0 & 0 \\
\hline & 歯肉側 & 0 & 0 & 1 & 0 & 0 & 0 & 0 & 0 & 1 & 1 & 1 & 0 & 0 & 0 & 1 & 0 & 0 & 0 & 0 & 0 & 0. 25 \\
\hline & 全 体 & 0 & 0 & 1 & 0 & 0 & 0 & 0 & 0 & 1 & 1 & 1 & 0 & 0 & 0 & 1 & 0 & 0 & 0 & 0 & 0 & 0.25 \\
\hline
\end{tabular}


表 4 無処理窩洞に複合レジンを充填した抜去歯の断面で観察された墨汁漏洩度 および偶角部気泡（温度変化24時間後）

\begin{tabular}{|c|c|c|c|c|c|c|c|c|c|c|c|c|c|c|c|c|c|c|c|c|c|c|}
\hline & No. & 1 & 2 & 3 & 4 & 5 & 6 & 7 & 8 & 9 & 10 & 11 & 12 & 13 & 14 & 15 & 16 & 17 & 18 & 19 & 20 & 平均 \\
\hline エナメル壁 & $\begin{array}{l}\text { 歯頂側 } \\
\text { 歯側 }\end{array}$ & $\begin{array}{l}+ \\
+\end{array}$ & + & $\begin{array}{l}+ \\
+\end{array}$ & + & $\begin{array}{l}+ \\
+\end{array}$ & $\begin{array}{l}+ \\
+\end{array}$ & $\overline{+}$ & + & $\begin{array}{l}+ \\
+\end{array}$ & $\begin{array}{l}+ \\
+\end{array}$ & $\begin{array}{l}+ \\
+\end{array}$ & $\begin{array}{l}+ \\
+\end{array}$ & + & $\begin{array}{l}+ \\
+\end{array}$ & $\begin{array}{l}+ \\
+\end{array}$ & + & $\begin{array}{l}+ \\
+\end{array}$ & $\begin{array}{l}+ \\
+\end{array}$ & $\bar{t}$ & $\begin{array}{l}+ \\
+\end{array}$ & $\begin{array}{l}0.9 \\
1.0\end{array}$ \\
\hline 象牙質側壁 & $\begin{array}{l}\text { 歯頂側 } \\
\text { 畨肉側 }\end{array}$ & + & $\begin{array}{l}+ \\
+\end{array}$ & $\begin{array}{l}+ \\
+\end{array}$ & $\begin{array}{l}+ \\
+\end{array}$ & + & $\begin{array}{l}+ \\
+\end{array}$ & $\bar{t}$ & $\begin{array}{l}+ \\
+\end{array}$ & + & $\begin{array}{l}+ \\
+\end{array}$ & $\begin{array}{l}+ \\
+\end{array}$ & + & $\begin{array}{l}+ \\
+\end{array}$ & $\begin{array}{l}+ \\
+\end{array}$ & $\begin{array}{l}+ \\
+\end{array}$ & $\begin{array}{l}+ \\
+\end{array}$ & $\begin{array}{l}+ \\
+\end{array}$ & $\begin{array}{l}+ \\
+\end{array}$ & $\overline{+}$ & $\begin{array}{l}+ \\
+\end{array}$ & $\begin{array}{l}0.9 \\
1.0\end{array}$ \\
\hline 窩底穿下部 & $\begin{array}{l}\text { 歯頂側 } \\
\text { 歯肉側 }\end{array}$ & + & $\begin{array}{l}+ \\
+\end{array}$ & $\begin{array}{l}+ \\
+\end{array}$ & + & + & $\overline{+}$ & $\bar{t}$ & $\begin{array}{l}+ \\
+\end{array}$ & $\begin{array}{l}+ \\
+\end{array}$ & $\begin{array}{l}+ \\
+\end{array}$ & $\bar{t}$ & $\begin{array}{l}+ \\
+\end{array}$ & + & $\begin{array}{l}+ \\
+\end{array}$ & $\begin{array}{l}+ \\
+\end{array}$ & $\overrightarrow{+}$ & $\begin{array}{l}+ \\
+\end{array}$ & + & $\overline{+}$ & $\begin{array}{l}+ \\
+\end{array}$ & $\begin{array}{l}0.8 \\
1.0\end{array}$ \\
\hline 窩底 & 中央部 & + & 一 & + & 一 & + & + & + & + & + & + & + & + & + & + & + & + & + & + & - & + & 0.9 \\
\hline 偶角部気泡 & $\begin{array}{l}\text { 歯頂側 } \\
\text { 歯肉側 }\end{array}$ & $\begin{array}{l}+ \\
+\end{array}$ & $\bar{t}$ & $\bar{t}$ & - & $\overline{+}$ & - & - & $\bar{t}$ & - & - & - & - & + & - & - & - & - & $\overline{+}$ & $\bar{t}$ & $\overline{+}$ & $\begin{array}{l}0.1 \\
0.45\end{array}$ \\
\hline \multirow{3}{*}{$\begin{array}{l}\text { 漏 洩 度 } \\
\text { (十数集計) }\end{array}$} & \multirow{2}{*}{$\begin{array}{l}\text { 歯頂側 } \\
\text { 歯肉側 }\end{array}$} & 4 & 3 & 3 & 3 & 3 & 2 & 0 & 3 & 3 & 3 & 3 & 3 & 4 & 3 & 3 & 2 & 3 & 3 & 0 & 3 & 2.7 \\
\hline & & 4 & 4 & 4 & 3 & 4 & 4 & 3 & 4 & 3 & 3 & 3 & 3 & 3 & 3 & 3 & 3 & 3 & 4 & 4 & 4 & 3.45 \\
\hline & 全 体 & 9 & 8 & 8 & 6 & 8 & 7 & 6 & 8 & 7 & 7 & 7 & 7 & 8 & 7 & 7 & 6 & 7 & 8 & 4 & 8 & 7.1 \\
\hline
\end{tabular}

表 5 エチルシアノアクリレート処理窩洞に複合レジンを充填した抜去歯の断面で観察された 墨汁漏洩度および偶角部気泡（温度変化24時間後）

\begin{tabular}{|c|c|c|c|c|c|c|c|c|c|c|c|c|c|c|c|c|c|c|c|c|c|c|}
\hline & No. & 1 & 2 & 3 & 4 & 5 & 6 & 7 & 8 & 9 & 10 & 11 & 12 & 13 & 14 & 15 & 16 & 17 & 18 & 19 & 20 & 平均 \\
\hline エナメル壁 & $\begin{array}{l}\text { 歯頂側 } \\
\text { 歯肉側 }\end{array}$ & \pm & $\overline{+}$ & $\overline{+}$ & $\overline{+}$ & - & $\overline{+}$ & - & - & $\overline{+}$ & - & + & $\bar{t}$ & - & $\overline{+}$ & $\overline{+}$ & - & $\overline{+}$ & - & - & \pm & $\begin{array}{l}0.15 \\
0.5\end{array}$ \\
\hline 象牙質側壁 & $\begin{array}{l}\text { 歯頂側 } \\
\text { 歯肉側 }\end{array}$ & - & $\bar{t}$ & - & - & - & $\overline{+}$ & - & - & $\overline{+}$ & - & - & $\bar{t}$ & $\overline{-}$ & - & $\overline{+}$ & - & - & - & - & - & $\begin{array}{l}0 \\
0.25\end{array}$ \\
\hline 窩底穿下部 & $\begin{array}{l}\text { 歯頂側 } \\
\text { 歯肉側 }\end{array}$ & - & - & - & - & - & $\overline{+}$ & - & - & $\overline{+}$ & - & - & $\overline{+}$ & - & - & $\overline{+}$ & 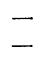 & $\overline{-}$ & - & $\overline{-}$ & - & $\begin{array}{l}0 \\
0.2\end{array}$ \\
\hline $\begin{array}{l}\text { 窩底 } \\
\text { 偶角部気泡 }\end{array}$ & $\begin{array}{l}\text { 中央部 } \\
\text { 歯頂側 } \\
\text { 歯肉側 }\end{array}$ & $\begin{array}{l}- \\
- \\
-\end{array}$ & - & - & $\begin{array}{l}- \\
- \\
-\end{array}$ & $\begin{array}{l}- \\
- \\
-\end{array}$ & $\begin{array}{l}- \\
- \\
-\end{array}$ & $\begin{array}{l}- \\
-\end{array}$ & - & $\begin{array}{l}+ \\
- \\
-\end{array}$ & $\begin{array}{l}- \\
-\end{array}$ & $\begin{array}{l}- \\
- \\
-\end{array}$ & $\begin{array}{l}- \\
- \\
-\end{array}$ & $\frac{-}{+}$ & $\begin{array}{l}- \\
- \\
-\end{array}$ & $\begin{array}{l}- \\
- \\
-\end{array}$ & $\begin{array}{l}- \\
- \\
-\end{array}$ & $\begin{array}{l}- \\
- \\
-\end{array}$ & $\begin{array}{l}- \\
- \\
-\end{array}$ & $\begin{array}{l}- \\
- \\
-\end{array}$ & $\begin{array}{l}- \\
- \\
-\end{array}$ & $\begin{array}{l}0.05 \\
0 \\
0.05\end{array}$ \\
\hline \multirow{3}{*}{ 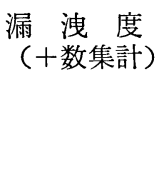 } & 歯頂側 & 1 & 0 & 0 & 0 & 0 & 0 & 0 & 0 & 0 & 0 & 1 & 0 & 0 & 0 & 0 & 0 & 0 & 0 & 0 & 1 & 0.15 \\
\hline & 歯肉側 & 0 & 2 & 1 & 1 & 0 & 3 & 0 & 0 & 3 & 0 & 1 & 3 & 1 & 1 & 3 & 0 & 1 & 0 & 0 & 0 & 1. 0 \\
\hline & 全 体 & 1 & 2 & 1 & 1 & 0 & 3 & 0 & 0 & 4 & 0 & 2 & 3 & 1 & 1 & 3 & 0 & 1 & 0 & 0 & 1 & 1.2 \\
\hline
\end{tabular}

より各群の成績を比較した結果（表 $2 \sim 5$ ),下記 の知見が得られた。

それによると，温度変化を与えなかった場合に は, 無処理のグループでは全体の平均漏洩指数は 6.65であるのに，シアノアクリレート処理したグ ループでは0.25であった。漏洩状態を具体的に述 ベると, 無処理のグループは, 全例で歯頂側, 歯 肉側の両側の窩底穿下部より深いところまで墨汁 が浸入していたのに対し，シアノアクリレート処 理したグループでは，4 例中 1 例にエナメル壁ま で墨汁浸入がみられるといら程度であった。
温度変化を与えた場合には，漏洩度は上昇し， 無処理のグループでは全体の平均指数は7.1 とな り：シアノアクリレート処理したグループでは 1.2 となったが, やはりシアノアクリレート処理 の有無による漏洩度の差は大きかった。

また，全例を通して歯頂側よりも歯肉側の方 が，漏洩度が大さかった。

c . 接着部断面の電子顕微鏡所見

走査型電子顕微鏡による，歯質と複合レジン充 填物との界面の観察から, 次のよらな所見が得ら れた（図10）。 


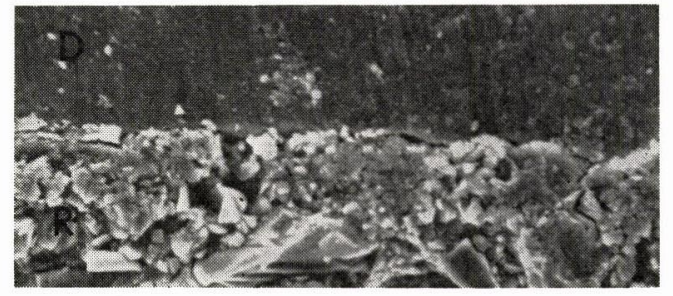

シアノアクリレート処理

$37 \mathrm{C}^{\circ}$ 蒸留水中

14日間保管

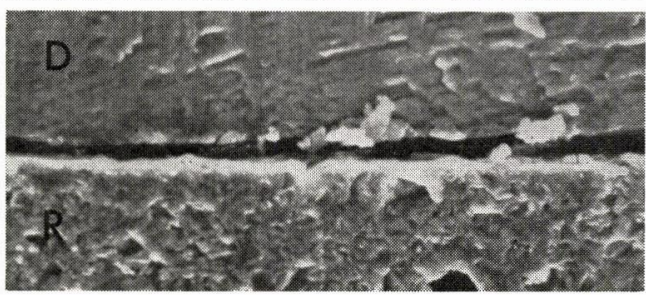

無処理

$37^{\circ} \mathrm{C}$ 蒸留水中

14 日間保管

図10 接着部断面の電子顕微鏡像

$\mathrm{D}$ ：象牙質 $\mathrm{R}$ ：複合レジン

無処理充填では, 歯質と複合レジン充填物との 間に約 $6 \sim 7 \mu \mathrm{m}$ の吵間を生じていたのに対し, シアノアクリレート処理充填では吵間を生じてい なかった。

\section{3. 漏洩に関する臨床試験成績}

口腔内の墨汁による漏洩試験により，次のよう な知見が得られた（図11，12）。

墨汁の渗透による辺縁部の黑線は, 填塞 1 週間 後の研磨時には, 無処理充填の大部分に発生した が，メチルシアノアクリレート処理充填では, ご く一部に限られ，エチルシアノアクリレート処理 充填では全く認められなかった。このような状況 は，填塞後 2 週間たっても変化なく，4 週間たっ ても特別な変化を示さなかった（表 6 ）。
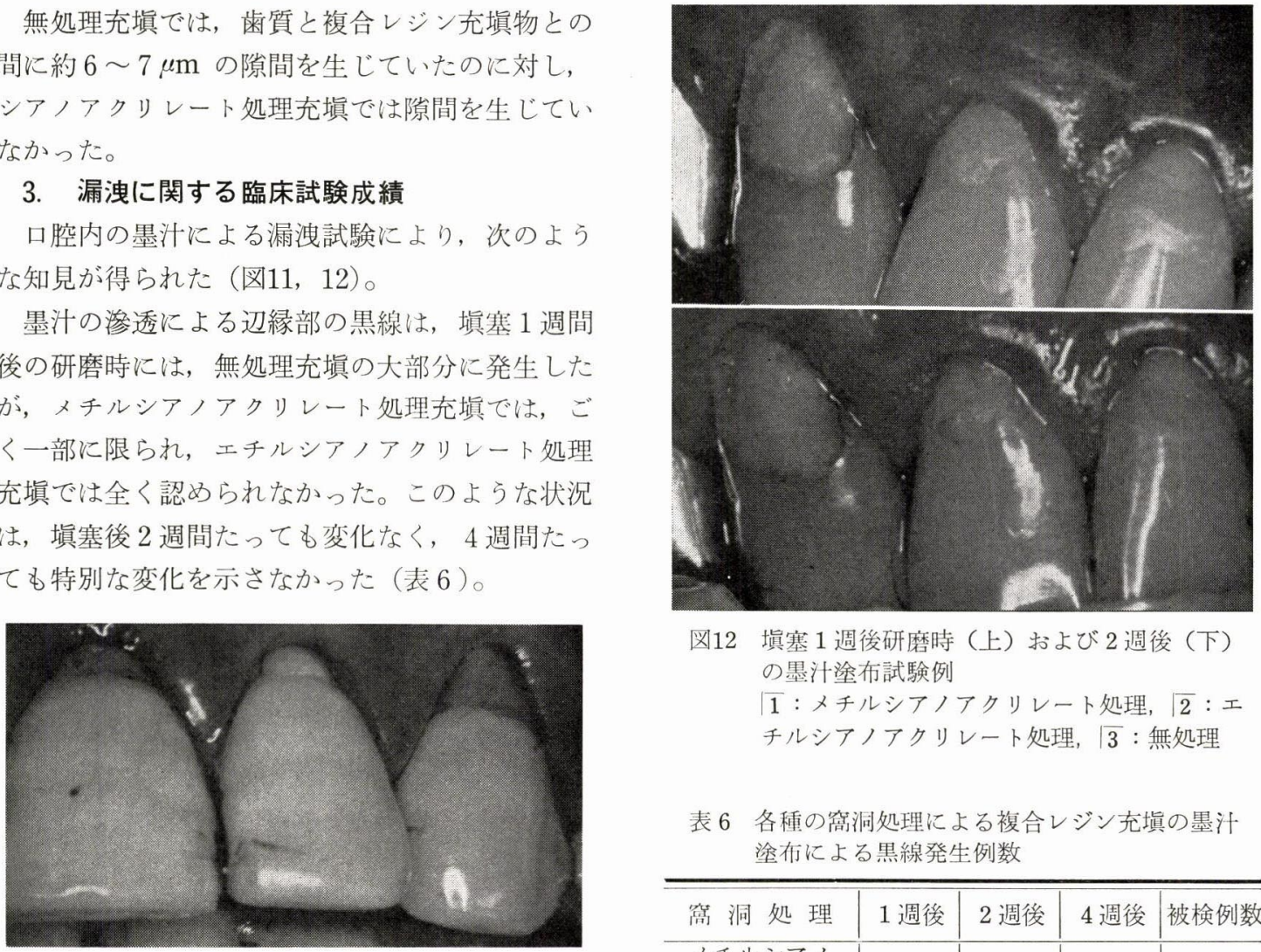

図12 眞塞 1 週後研磨時（上）および 2 週後（下） の墨汁塗布試験例

1：メチルシアノアクリレート処理, $\sqrt{2}$ : エ チルシアノアクリレート処理, $\mid \overline{3}:$ 無処理

表 6 各種の窩洞処理による複合レジン充填の墨汁 塗布による黒線発生例数

図11 填塞 1 週間後研磨墨汁塗布の口内試験例 1 : 無処理, 12 ：メチルシアノアクリレ 一ト処理, 3 : 無処理

\begin{tabular}{|c|c|c|c|c|}
\hline 窝 洞 処 理 & 1 週後 & 2 週後 & 4 週後 & 被検例数 \\
\hline $\begin{array}{l}\text { メチルシア， } \\
\text { アリリレート }\end{array}$ & 3 & 3 & 3 & 19 \\
\hline $\begin{array}{l}\text { エチルシア， } \\
\text { アクリレート }\end{array}$ & 0 & 0 & 0 & 19 \\
\hline 無 処 理 & 16 & 16 & 15 & 19 \\
\hline
\end{tabular}


表 7 各種窩洞処理による複合レジン充填の 歯髄刺激発生状態

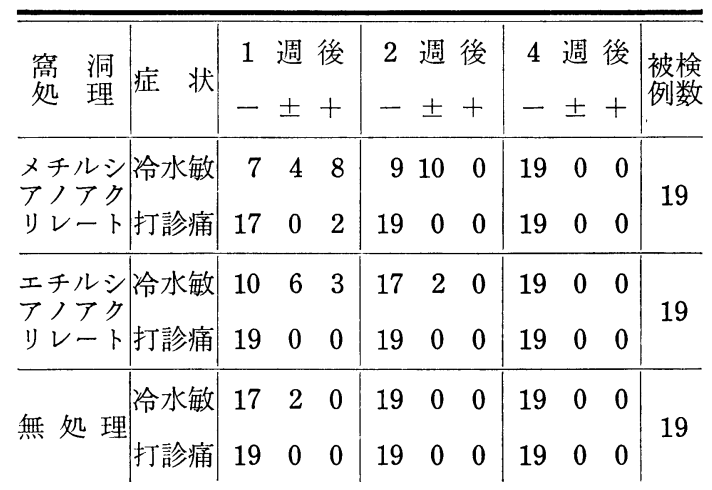

\section{4. 歯髄刺激に関する臨床試験成績}

メチルシアノアクリレートあるいはエチルシア ノアクリレートにより窩洞処理を行った充填と無 処理充填との間には, 歯髄刺激の発生状態に関し て，下記のような差が認められた（表 7）。

充塞 1 週間後の研磨時には, 無処理充填では臨 㕅的不快症状はほとんどみられなかったが，メチ ルシアノアクリレート処理充填の場合には, 半数 以上に冷水に対する知覚過敏が現れ，ごく少数に は打診痛も現れた。エチルシアノアクリレート処 理充填の場合には約半数に冷水過敏が現れたが, 打診痛を示すものはなかった。これに対して, 無 処理群では，ごく少数にわずかな冷水過敏が認め られるのみであった。

このよらな症状は填塞後 2 週間経過すると, ご く軽いもののみとなり, メチルシアノアクリレー 卜処理充填の約半数, エチルシアノアクリレート 処理充填のごく少数にのみ認められたが, 無処理 群では完全に消失していた。填塞後 4 週間経過す ると，いずれの方法で窩洞処理を行った群でも， 臨床的不快症状はすべて消失していた。

\section{考察}

\section{1. シアノアクリレート処理と接着力}

シアノアクリレートは, 電気・電子工業, カメ ラ時計などの精密工業, 自動車工業など工業界で いろいろな方面に多用されており，現在では一般 家庭でも，簡便な瞬間接着剤として用いられてい
る。

この接着剂は, 瞬間的に重合し, 強力な接着力 を示すといら点, 無色透明であるといら点など優 れた特性をるつので, その特性を歯科医学, 特に 保存修復学に応用する可能性の追求のために, 歯 質をシアノアクリレートで処理し, 複合レジンを その上飞填塞し，接着力を測定した。

シアノアクリレートの接着力は, 乾燥した歯質 に対しては強力であるといわれ222, 本研究におい てもかなりの接着力を示し, 特にェナメル質より も象牙質に強い接着力を示したが，これは次のよ らな理由によるものであるう。

シアノアクリレートは, 強塩基, 弱塩基, 水ま たはアルコールなど $\mathrm{OH}^{-}$を有する物質の存在下 で主鎖のエチンン構造がアニオン重合して樹脂 化し, 強力な接着力を示するのと考光られてい $3^{28)}$ 。この場合重合の触媒となった基は, 重合体 の末端基となっているので29)，歯質に触媒となる 基があれば，シアノアクリレートと歯質は化学的 に結合すると思われる。

歯質に含まれている物質の中で，シアノアクリ レートの重合の触媒となると思われるものは，水 分と有機質であるが299，これらはエナメル質には $3 \%$ しか含まれていないのに，象牙質には $31 \%$ 含 まれている30)。象牙質への接着力が特に強かった のは，化学的な結合が象牙質の方が多くできるた めであろう。

ところが，本研究において水中に保管すると， 2 週間後には接着力が零に近いものとなってしま った。これは，極性接着剤であるシアノアクリレ 一トが無極性である歯質表面淁着すると，極性 物質である水分が容易に両者間の界面に浸入する ことによるものと推測されている31)。また，シア ノアクリレートの重合体は, 加水分解をして重合 を解き，ホルムアルデヒドを発生するが322，これ も接着力の低下に関保あると思われる。したがっ て，唾液により常に湿潤した口腔内に施される修 復物に拄いては, シアノアクリレートの接着力に 頼って䈑洞に保持形態を付与することを省くこと は，不可能であると考光られる。 


\section{2. シアノアクリレート処理の漏洩防止効果}

上記のよらにシアノアクリレートは歯質に対し て永続的な接着力を有しないにも拘らず，これに 上る䈑壁の处理は, 明らかに複合レジン充媜の漏 洩を防止し，このことは温度変化を与えても変わ らなかった。

そこで接着部断面を電子顕微鏡により観察した ところ, シアノアクリレート処理した简洞では, 歯質と充媜物とが密着していたが，無処理の窩洞 では $6 \sim 7 \mu \mathrm{m}$ の㭞間が生じていた。無処理の䈑 洞中では，レジンが硬化時の重合収縮により，歯 質との間に吵間を生じ33)，そこ汇墨汁が浸入する のであるが，シアノアクリレート処理した場合に は, シアノアクリレートの接着力が十分ある時期 に, 複合レジンが硬化するので, 重合収縮による 剥離が障げられて吵間が生じず，そのために漏洩 が起こらないものと思われる。このよらな緊密な 適合状態は, シアノアクリレートが水分によって 接着力を失った後にも保たれ, また温度変化が与 えられても注とんど変わらないことが本実験で明 らかになった。

\section{3. 歯髄刺激}

シアノアクリレート処理を行らと, 複合レジン 充填の歯䯣刺激をわずかに増大した。シアノアク リレート処理を行った場合には, 歯質と充媜物と は良好飞適合して打り，口腔内から歯䯣を刺激す る物質が両者の間に入り込むとは考光にくく，乙 たがってシアノアクリレート自体が起こした刺激 であるらと思われる。

このような歯髄刺激の原因としては, シアノア クリレートが重合する際に歯細管内の水分が奪わ れてその内压が変化し，それが刺激となり歯髄に 対して影響を及ぼす可能性がある ${ }^{34)}$ 。李た重合体 の加水分解により生じたホルムアルデヒドが歯䯣 を刺激する可能性があるとされている35)。シア， アクリレートのメチルとェチルとではメチルのほ うが強い歯髄刺激を生じたが，これはメチルのほ うが加水分解を起こしやすいためと考えられる 29)。

しかし,このような刺激を生じ臨床的症状は,
充媜後 2 週間で大部分消失し，4 週間後には完全 に消失していた。Bhaskar らの研究によると， シアノアクリレートを䈑洞に用いた場合には， 3 週間で 6 例中全例飞第 2 象牙質の形成をみたと報 告しているので36)，このような刺激症状の消失は 第 2 象牙質形成に関係があるか子知れない。

\section{4. シアノアクリレートの選択}

本実験では 2 種のシアノアクリレート（メチル シアノアクリレートとエチルシアノアクリレー ト）を窩洞処理のため用いたが，両者間には下記 のような差が認められた。すなわち接着力は, 空 気中保管では両者の間に大きな差は認められなか ったが，温水中保管ではエチルシアノアクリレー トのほうがやや強かった。漏洩もエチルシアノア クリレートのほらが少なかった。また歯髄に対す る刺激もエチルシアノアクリレートのほらが少な かった。

以上のことから，複合レジン充填の䈑洞処理に は, メチルシアノアクリレートよりも, エチルシア ノアクリレートのほうが適していると思われる。

\section{総 括}

シアノアクリレート処理のレジン充填へ及ぼす 効果を調べるために, 歯檤をシアノアクリレート により処理した場合としなかった場合に抢ける複 合レジン充填の接着力を測定比較した。また，抜 去歯牙の 5 級筒洞の複合レジン充媜について，そ の漏洩度を墨汁によって調べ，その接着断面を電 子顕微鏡により観察した。また, 臨床試験におい て子墨汁による漏洩試験と歯䯣刺激の発生状態を 調べた。

1. シアノアクリレートは空気中に保管した状 態では, 歯質に対しかなりの接着力を示したが, 温水中に保管した状態では, 接着力は低下し, 非 常に微弱なものになってしまった。

2. シアノアクリレート処理した場合には, 象 牙質注対する接着力は，エナメ儿質に対する接着 カより大きかった。

3. 空気中に保管した場合には，ィチルシア， アクリレート処理の接着力もェチルシアノアクリ 
レート処理の接着力も大きな差はなかったが, 温 水中に保管した場合には，エチルシアノアクリレ 一トのほうが接着力が大きかった。

4. シアノアクリレート処理した上に填めた 2 種の複合レジンの間には, 接着力の差はなかっ た。

5. シアノアクリレート処理した複合レジン充 填と, 無処理の複合レジン充填とでは, シアノア クリレート処理したものが，漏洩が少なかった。

6. 上記の試験を温度変化を与えながら行った が，やはり無処理とシアノアクリレート処理とで は, その差は著しく, シアノアクリレート処理群 では，漏洩が少なかった。

7. 電子顕微鏡による所見では, 歯質と充填物 との間にシアノアクリレート処理したものでは吵 間はなかったが，無処理のものでは $6 〜 7 \mu \mathrm{m}$ の 隙間があった。

8. 臨床試験でも, 無処理のものは漏洩が大き かったが，シアノアクリレート処理したものでは 漏洩は少なく，特にェチルシアノアクリレート処 理したものでは, 漏洩はなかった。

9. シアノアクリレート処理は歯髄刺激をわず かに増大したが，その程度はメチルシアノアクリ レートよりも，エチルシアノアクリレートのほう が少なかった。

\section{謝 辞}

稿の終わりに際して, 御指導, 御校閲いただいた東 京医科歯科大学第 1 保存学教室の総山孝雄教授，なら びに終始御指導御援助をいただいた岩久正明助教授, 電子顕微鏡写真撮影飞御協力下さった東京医科蒾科大 学医用器材研究所無機材料部の柴満生技官に心からの 感謝の意を棒げます。

\section{文献}

1) Buonocore, M. G.: A simple method of increasing the adhesion of acrylic filling materials to enamel surfaces. J. Dent. Res., 34: 849-853, 1955.

2) Buonocore, M., Wileman, W. \& Brudevold, E.: A report on a resin composition capable of bonding to human dentin surfaces. J. Dent. Res., 35: 846-851, 1956.
3) Buonocore, M. G., Matsui, A. \& Gwimett, A. J.: Penetration of resin dental materials into enamel surfaces with reference to bonding. Archs. Oral Biol., 13: 61-70, 1968.

4）谷 嘉明,竹内正敏,井田一夫 : 複合レジン修復 材に打ける接着強化法の比較, その 1 エナメル 質への接着性. 器材学誌, $33: 326,328,1976$.

5) Vojinovic, O., Nyborg, H. \& Bränström, M.: Acid treatment of cavities under resin fillings: Bacterial growth in dentinal tubules and pulpal reactions. J. Dent. Res., 52: 1189-1193, 1973.

6) Olgart, L., Brännström, M. \& Johnston, G.: Invasion of bacteria into dentinal tubules. Acta Odont. Scand., 32: 61-70, 1974.

7) Liatukas, E. L. \& Young: Scanning electron microscopy of enamel crack after etching: An in vitro study. J. Prosthet. Dent., 33: 558-561, 1975.

8) Bowen, R. L.: Adhesive bonding of various materials to hard tooth tissues. I. Method of determing bond strength. J. Dent. Res., 44: 690-695, 1965.

9) Bowen, R. L.: Adhesive bonding of various materials to hard tooth tissues. II. Bonding to dentin promoted by a surface-active comonomer. J. Dent. Res., 44: 895-902, 1965.

10) Bowen, R. L.: Adhesive bonding of various materials to hard tooth tissues. III. Bonding to dentin improved by pretreatment and the use of surface-active conomer. J. Dent. Res., 44: 903-905, 1965.

11) Bowen, R. L.: Adhesive bonding of various materials to hard tooth tissues. IV. Bonding to dentin, enamel and fluoapatite improved by the use of a surface-active comonomer. J. Dent. Res., 44: 906-911, 1965.

12) Bowen, R. L.: Adhesive bonding of various materials to hard tooth tissues, V. The effect of a surface-active comonomer on adhesion to diverse substrates. J. Dent. Res., 44: 13691373, 1965.

13）大串貫太郎，ほか：第22回日本歯科保存学会総 会, 東京, 1975 .

14) Smith, D. C.: A new dental cement. Brit. Dent. J., 125: 381-384, 1968.

15）岩久正明, 斎藤允昭, 清水芳保, 的野良次：力 ルボキシレートセメントの潾骾刺激について。 日歯保誌, $14: 254-259,1972$.

16）岩久正明, 他 6 名：カルボキシレートセメント の研究, (その 2) 接着について. 器材学誌, $29: 35-39,1973$.

17）総山孝雄：歯質にキレートする新接着材一カル 
ボキシレートセメントについて，菌界展望， $40: 225-229,1972$.

18) Wilson, A. D. \& Kent, B. E.: A new translucent cement for dentistry. Brit. Dent. J., 132: 133-135, 1972.

19) Mclean, J. W. \& Wilson, A. D.: The clinical development of the glass-ionomer cement, III The erosion lesion. Aus. Dent.J., 22: 190-1977.

20) Mclean, J. W. \& Wilson, A. D.: The clinical development of the glass-ionomer cememt. I formulation and properties. Aus. Dent. J., 22: 31-36, 1977.

21）黑崎紀正, 他 7 名: カルボキシレートセメント の研究, (その 1) 物理化学的性質について. 器材学誌, $29: 31-34,1973$.

22) Beech, D. R.: Bonding of alkyl 2-cyanoacrylates to human dentin and enamel. J. Dent. Res., 51: 1438-1442, 1972.

23）総山孝雄 : 新レジン充冝. 京都, 1973, 永末書 店, 24-28ページ.

24）岩久正明 : 複合レジン充填の臨床成績について. 日歯保誌, $16: 282,1973$.

25）小林久紀 : 複合レジン修復の辺縁封鎖性に関す る研究. 歯科医学, $36: 33-59,1973$.

26) Jørgensen, K. D. \& Asmussen, E.: Pseudodiscoloration of plastic fillings. Acta Od. Sc., 29: 649-652, 1971.
27）日本電子顕微鏡学会関東支部：走査電子顕微鏡. 東京, 1976, 共立出版.

28）太田和夫：生体と接着剂。接着，12:170-177, 1968.

29) Leonard, F., Hulkarni, R. K., Brandes, G., Nelson, J. and Cameron, J. J.: Synthesis and degeneration of poly (alkyl $\alpha$-cyanoacrylates). J. Appl. Polym. Sci., 10: 259-272, 1966.

30）押鐘 篤, ほか：歯科生化学. 東京, 1976, 医 歯薬出版社, 150ページ.

31）山木昌雄, 中沢省三 : 歯科用レジン系接着剤の 最近の進歩. 広大歯誌, $7: 1-17,1975$.

32）杉山岩吉：シアノ系接着昘の耐久性と問題点. 接着, $13: 312-318,1969$.

33) Asmussen, E. \& Jørgensen, K. D.: A microscopic investigation of the adaptation of some plastic filling materials to dental cavity walls. Acta Odont. Scand., 30: 3-21, 1972.

34）河村洋二郎：象牙質知覚をめぐる諸問題. 歯界 展望, 36 : 197-204, 1970.

35) Matsui, A., Buonocore, M., Sarda, O. \& Yamaki, M.: Tissue reactions to methyl-and Ethyl-2cyanoacrylate adhesives. J. Dent. Res., 46: 389-394, 1967.

36) Bhaskar, S. N., et al.: Pulpal response to four restorative materials. O. S. O. M. \& O. P. 28: 126-133, 1969. 